\title{
DEMENSI BUDAYA LOKAL DALAM TRADISI HAUL DAN MAULIDAN BAGI KOMUNITAS SEKARBELA MATARAM
}

\author{
Oleh : Abd. Kadir Ahmad
}

\section{PENDAHULUAN}

Penelitian ini dilakukan di Kotamadya Mataram Nusa Tenggara Barat. Sasaran penelitian adalah suatu masyarakat lokal yang menamakan dirinya orang Sekarbela, berdiam di Kelurahan Karang Pule Kecamatan Ampenan Kotamadya Mataram. Mereka menarik untuk dijadikan fokus penelitian, karena dengan nama khas Sekarbela, mereka menampilkan prilaku keagamaan yang dalam banyak hal berbeda dengan komunitas Islam sekitarnya, terutama dalam tradisi haul dan dalam memperingati Maulid Nabi Muhammad saw.

Sebagai bagian dari budaya daerah yang secara operasional dijadikan sebagai alat untuk menangkal dampak budaya asing yang tidak sesuai dengan nilai-nilai luhur dan kepribadian bangsa, identifikasi terhadap budaya lokal semacam itu menjadi amat penting atas dasar berbagai pertimbangan. Pertama, pesatnya kemajuan ilmu pengetahuan dan teknologi telah mendorong interaksi antar bangsa, terutama teknologi komunikasi dan transportasi, mengakibatkan derasnya arus informasi dan masuknya nilainilai ajaran agama dan nilai-nilai budaya luhur budaya bangsa. Kedua, masuknya nilainilai yang bertentangan tersebut mengakibatkan terjadinya pendangkalan nilai-nilai moral dan nilai-nilai luhur budaya bangsa, yang pada akhirnya dikhawatirkan akan mengakibatkan terjadinyqa krisis jati diri kepribadian bangsa. Ketiga, masyarakat Indonesia belum sepenuhnya mempunyai daya tangkal yang handal dan kemampuan untuk memilih dan memilah berbagai pengaruh dari luar, se- hingga dampak negatif globalisasi dapat dihindari. Keempat, perlunya memperkuat jati diri dan kepribadian bangsa Indonesia sehingga mempunyai ketahanan sosial budaya yang tangguh dan handal.

Fokus penelitian adalah perwujudan agama dalam upacara haul dan maulid, dua jenis upacara keagamaan yang secara tradisional hidup dan berlaku dalam sistem budaya masyarakat Sekarbela. Upacara tradisional tersebut dilaksanakan setiap tahun dan dianggap sebagai upacara suci dengan corak spesifik yang amat mencerminkan nuansa lokal. Dengan demikian penelitian bertujuan untuk memperoleh pengetahuan mengenai corak kehidupan keagamaan dalam konteks lokal, yang memperlihatkan ekspresi keagamaan yang khas.

Yang dimaksud dengan upacara keagamaan dalam penelitian ini adalah upacara yang bersifat keramat/suci yang berhubungan dengan peristiwa dalam rangka suatu sistem keyakinan yang bersumber pada ajaran-ajaran dalam sistem itu telah terwujud sebagai tradisi dalam masyarakat. Dalam pengertian tradisi tersebut, tercakup pengertian kuat dalam sistem budaya dari suatu kebudayaan yang menata tindakan manusia dalam kehidupan sosial kebudayaan itu (Koentjaraningrat dkk. $1984: 2$ ).

Sehubungan dengan pengertian tersebut, konsep-konsep dasar yang perlu dijelaskan dalam penelitian ini adalah berkaitan dengan agama dan upacara atau upacara dan agama serta kaitan hubungan antara keduanya. Ajaran dalam pengertian ini dipahami sebagai suatu sistem keyakinan yang dianut dan tindakan-tindakan yang diwujudkan oleh 
suatu kelompok atau masyarakat dalam menginterpretasikan dan memberi respons terhadap apa yang dirasakan dan diyakini sebagai suci (Suparlan, 1988 : v-vi). Sedangkan upacara dapat dilihat sebagai sistem aktivitas atau rangkaian tindakan yang ditata oleh adat atau hukum yang berlaku yang berhubungan dengan berbagai macam peristiwa tetap yang biasanya terjadi dalam masyarakat yang bersangkutan (Koenjtaraningratdkk., 1984 : 1989).

Dengan pengertian seperti itu, pertalian agama dan upacara secara jelas dapat diidentifikasi. Upacara dapat dilihat sebagai salah satu corak perwujudan agama dalam kehidupan sehari-hari bagi penganut agama yang bersangkutan. Tindakan yang bertujuan mencari hubungan dengan dunia gaib yang dilaksanakan menurut tata kelakuan yang baku pada dasarnya merupakan upacara keagamaan yang menurut Koentjaraningrat (1985 : 243), terdiri dari empat komponen yaitu : (1) tempat upacara, (2) saat upacara, (3) benda-benda dan alat-alat upacara, dan (4) orang yang melakukan dan memimpin. Semua komponen upacara tersebut bersifat sakral. Dalam kenyataannya, upacara keagamaan itu dapat terwujud dalam bentuk (1) bersanji, (2) berkurban, (3) berdoa, (4) makan bersama, (5) menari dan menyanyi, (6) berprosesi, (7) memainkan seni drama, (8) berpuasa, (9) intoksikasi, (10) bertapa, dan (11) bersamadi (Koentjaraningrat, 1985 : 235).

Pendekatan yang digunakan dalam penelitian ini adalah holistik atau sistematik, yaitu memperlakukan sebuah masyarakat sebagai bagian unsur-unsur sosial budaya dalam hubungan struktural fungsional yang saling berkaitan antara satu dengan lainnya dan secara keseluruhan merupakan sebuah satuan utuh dan menyeluruh. Dalam pendekatan seperti ini, haul dan maulid sebagai sasaran kajian diperlakukan sebagai sebuah kasus.

Sesuai dengan pendekatan yang di- gunakan dalam penelitian ini, maka pengumpulan data dilakukan melalui metode-metode (1) Studi kepustakaan, yaitu mempelajari dokumen-dokumen atau tulisan-tulisan yang berkaitan dengan masyarakat atau kebudayaan setempat, (2) wawancara mendalam dengan informan kunci yang terdiri atas Tuan Guru, penghulu, dan pemuka agama lainya; pemuka adat/masyarakat, pejabat pemerintah dan pendukung upacara tersebut serta warga masyarakat lainnya; (3) Pengamatan terlibat struktur kegiatan masyarakat sehari-hari, dan ketika upacara maulid berlangsung. Sayang sekali metode ini tidak dapat dilakukan untuk upacara haul karena kebetulan waktu penelitian sulit dikompromikan dengan waktu pelaksanaan haul.

Dari penelitian ini ditemukan bahwa ternyata kedua upacara tersebut (haul dan maulid) tetap mampu mempertahankan eksistensinya dan kelestariannya; dan dalam kelestarian itu nuansa lokal mewujudkan diri dalam bentuk mengkota dan modern. Dalam penampilan upacara yang dipentingkan bukan makna material dari upacara haul dan maulid akan tetapi lebih pada makna simbolis, berupa kecintaan kepada tokoh yang diperingati dalam hal ini Tuan Guru Muhammad Rais untuk upacara haul, dan Nabi Muhammad untuk upacara maulid. Resistensi haul dan maulid dalam aroma lokal dan tradisional mengalami penguatan dari adanya tantangan dari luar (modernintas di satu sisi dan tarikan sejarah kepahlawanan orangorang Sekarbela dalam mempertahankan bendera Islam di tengah pergulatan IslamHindu di zaman Penjajahan Anak Agung dari Bali.

\section{SEJARAH DAN REALITAS KEISLAMAN}

Hampir $90 \%$ orang Sasak beragama Islam. Di Karang Pule sendiri data keagamaan menunjukkan Islam 12.635 orang, Kristen 14 orang, Katolik 11 orang, Hindu 
DIMENSIBUDAYA LOKAL DALAM TRADISI HAUL

DAN MAULIDAN BAGIKOMUNITAS SEKARBELA MATARAM

162 orang. Konsentrasi pemeluk non-Islam, khususnya Hindu', berada di Lingkungan Karang Pule. Perbandingan dengan sarana peribadatan meliputi mesjid 11 buah, musholla 15 buah, dan pura 1 buah.

Sejarah Islam di Sekarbela diawali dari cerita masyarakat yang menyebutkan adanya seorang tokoh bernama Gaus Abdul Razak yang dipercayai sebagai wali dan guru masyarakat Sekarbela. Gaus disebutkan berasal dari kalangan wali sembilan, Persia, atau dari Bagdad (Irak). Gauslah yang pertama kali mempelopori berdirinya mesjid pertamadi daerah itu. Konstruksi mesjid tersebut menyerupai payung, terbuat dari alang-alang dengan tiang hanya satu (tiang guru) di bagian tengah bangunan. Meski sederhana, konstruksi mesjid juga dilengkapi dengan mimbar. Suatu ketika, di bawah mimbar tiba-tiba muncul mata air yang cukup besar. Peristiwa itu diabadikan dalam etiologi Sekarbela dengan apa yang mereka sebutkan mxbenga' (mengherankan, ajaib). Sekarang mata air tersebut sudah merupakan kolam dimana masyarakat setempat memanfaatkan untuk berbagai kebutuhan. Keajaiban air itu dikaitkan dengan munculnya mata air persis di depan mimbar mesjid; mata air tersebut cukup besar untuk ukuran keperluan rumah tangga orang-orang Sekarbela yang ada di sekitarnya dan tidak pernah kering meski di musim kemarau; dipercayai bahwa air tersebut hanya mau mengalir ke arah barat dan tidak mau mengalir ke arah timur (Zainul Islam' 1995 : 2).

Gaus Abdul Razak bukan saja menyebarkan Islam di Sekarbela, tetapi juga kebagian selatan Lombok. Ia memiliki murid sampai ke Pagutan dan sekitarnya. Sebagai seorang yang dipercayai sebagai wali dan memiliki pengaruh cukup kuat di bawah dominasi Kerajaan Hindu Bali yang pada waktu itu menjajah Lombok, banyak cerita dramatis berkembang berkenaan dengan tokoh tersebut dalam masyarakat Sekarbela. Anak Agung yang ada di wilayah Bongor dikisahkan sebagai sangat khawatir akan luasnya pengaruh Gaus. Apalagi setelah tersiar berita bahwa Gaus dapat berada di dua tempat pada waktu yang sama.

Ceritanya berawal dari adanya hajatan murid-murid Gaus di Pagutan untuk mengadakan selamatan. Karena sampai tiba saat acara akan dimulai Gaus belum juga hadir, diutuslah dua orang murid menjemput beliau ke Sekarbela. Akan tetapi sesampai di sana, ternyata Gaus sejak dari tadi meninggalkan Sekarbela menuju Pagutan. Dalam perjalanan kembali ke Pagutan, kedua utusan melihat gurunya itu berada di kerumunan orang-orang yang tengah bermain sabung ayam. Dalam keadaan bimbang dengan kejadian tersebut, keduanya menyampaikan kesaksian itu kepada orang-orang di Pagutan, namun keduanya mendapat marah karena sebenarnya guru mereka telah tiba semenj-ak tadi dan telah lama di dalam mesjid.

Merasa tidak aman dengan perkembangan pengaruh Gaus itulah membuat Anak Agung berusaha membunuhnya. Sang Guru kemudian berhasil diculik dan dibawah ke suatu tempat dekat Kuranji dimana ia dihabisi dan pembunuhnya ternyata muridnya sendiri yang tidak loyal dan bertindak sebagai pembunuh bayaran. Masyarakat percaya, bahwa pembunuh wali suci itu kemudian mendapat kutukan tujuh turunan dan mengalami penyakit fisik seperti buta dan penyakit mengerikan lainnya. Atas jasa baik dari Anak Agung Jelantik, yang memang memiliki hubungan baik dengan Sekarbela, warga Sekarbela dapat menemukan lokasi pembunuhan dimaksud tetapi mereka tidak menemukan mayat sang guru kecuali bekas tetesan darah yang membuat rerumputan di sekitarnya seperti terbakar. Dengan darah itu dilakukan pemakaman secara simbolis tepat di pinggir sebuah kali dimana darah ditemukan. Makam Gaus Abdul Razak kemudian dikenal sebagai makam Padang Reak (padang : rumput, reak : terbakar). Dalam perjalanan pulang, menyusuri pantai Kuranji, mereka 
DIMENSIBUDAYA LOKAL DALAM TRADISI HAUL DAN MAULIDAN BAGIKOMUNITAS SEKARBELA MATARAM

tiba-tiba melihat Gaus Abdul Razak di dalam laut mengenakan jubah putih sambil berseru :

- Teruskan syiar Islam

- Salam saya untuk semua warga Sekarbela karena saya akan pergi selamanya.

- Datanglah di makam ini setiap tahun setelah Iedil Fitri.

Setelah menyampaikan pesan, Gaus melambaikan tangan dan menunggang kudanya ke arah barat sampai menghilang dari pandangan. Tempat singgah Gaus secara simbolis juga dijadikan makam yang sewaktu-waktu dapat dilihat hanya oleh mereka yang beruntung.

Pesan tersebut senantiasa dilestarikan masyarakat Sekarbela dan setiap tahun setelah upacara Iedil Fitri mereka pergi ke Padang Reak untuk ziarah. Makam Padang Reak dipercayai memiliki hubungan dengan Benga'. suatu waktu masyarakat lalai sehingga tidak mempat ziarah ke Padang Reak, tanpa dinyana air Benga' menjadi kering dan banyak warga terkena penyakit. Setelah disadari penyebabnya dan mereka kemudian melakukan ziarah ke Padang Reak barulah kondisi air normal kembali.

Kesedihan warga Sekarbela dengan wafatnya guru mereka yang sangat dicintai berbuntut menjadi dendam terhadap Anak Agung Bongor. Dengan dibantu Dea Mumbul' masyarakat Sekarbela melakukan perlawanan terhadap Anak Agung Bongor. Meski bertahan di sebuah tempat yang kemudian dikenal bernama Taker (bertahan) di daerah Pagutan pasukan Anak Agung terdesak mundur ke timur mendekati Cakranegara dinaman Anak Agung terjatuh dan babak belur (sehingga sekarang disebut Babakan). Anak Agung terus diburu sampai di suatu tempat yang sekarang disebut Karang Siluman, ia menghilang sampai ditemukan kembali dalam keadaan terjerembab dalam sebuah lobang dan akhirnya terbunuh. Tempat itu sekarang disebut Karang Belumbang di kawasan Cakranegara. ${ }^{2}$

No. 14 Th. DC Juli/Desember 1997
Dari aspek historis dan sosiologis, Sekarbela dapat dikatakan identik dengan Islam. Identifikasi dan karakterisasi komunitas sebagai "Pembela Islam" (sebagai arti dari Sekarbela) berlangsung dalam tempo dan semangat yang relatif konstan. Hal ini disebabkan adanya kekuatan sejarah komunitas yang ditandai dengan munculnya secara berkesinambungan tokoh agama sebagai faktor dominan dalam membangun sebuah solidaritas dan identitas kelompok sampai sekarang. Sesudah periode Gaus muncul Tuan Guru Muhammad Rais pada periode berikutnya, dan sekarang periode generasi putra-putra dan murid-muridnya. TGH Muhammad Rais adalah seorang Tuan guru (Ulama) besar dan berpengaruh di Lombok, hidup pada penghujung abad ke-19 awal abad ke-20. Ialah yang menjadi sumber genealogi keilmuan Islam dimana dari tangannya lahir Tuan Guru-Tuan Guru di Sekarbela dan di daerah lain di Lombok sampai sekarang. Istilah Tuan Guru dipergunakan untuk mereka yang memiliki profil kyai/ulama di masyarakat lain. Pi Sekarbela tokoh Islam yang bergelar Tuan Guru sekarang adalah TGH. Mustafa, TGH. Marzuki, TGH. Muhammad Rais, dan saudaranya TGH. Drs. Maksud Rais. Upaya lebih mengembangkan ajaran Rais kemudian diwujudkan dalam bentuk pendirian Pondok Pesantren Arraisiyah oleh anak-anak, murid-murid dan masyarakat Sekarbela.

Kondisi demikian membuat Sekarbela menjadi semacam enclave bagi kehidupan keIslaman di Mataram, dimana semangat keagamaan terpaut secara integral dalam sejarah komunitas lembaga pendidikan, lembaga ekonomi, dan budaya lokal. Spirit ke-Islaman masyarakat antara lain ditandai dengan besaraya minat pergi haji.

Di Sekarbela dan Lingkungan Karang Pule sekitar 600 orang haji. Sebagian besar dalam benaknya, ada niat Insya Allah kalau saya dapat 
DMENSI BUDAYA LOKAL DALAM TRADISI HAUL

DAN MAULIDAN BAGI KOMUNITAS SEKARBELA MATARAM

uang secukupnya, akan pergi haji. Jarang berkeinginan beli raobil. Tapi setelah pergi haji pengusahapengusaha itu berhasil, banyak punya mobil. Kalau sebelum haji dicela sama masyarakat "masak punya banyak uang tidak mau pergi haji". Sudah pulang dari Mekah baru cari mobil, cari apa. Laki dan perempuan, begitu. Suami isteri. Atau suami dulu. Banyak juga yang belum nikah sudah haji. ${ }^{3}$

Selain terkait dengan faktor ekonomi, nilai haji di mata masyarakat Sekarbela berimplikasi pada naiknya status sosial dan keagamaan seseorang. Dalam upacara ritual dan seremonial para haji menempati posisi khusus dalam strata pelapisan peserta upacara. Tingginya prestise yang diberikan nilai haji kepada penyandangnya membuat masyarakat Sekarbela meletakkan ujung dari keberhasilan usahanya terkait dengan niat menunaikan ibadah haji. Atau dengan kata lain, tanda keberhasilan seseorang dalam berusaha adalah jika dia sudah membuktikan diri mampu melaksanakan ibadah haji. Itulah sebabnya, bagi suatu komunitas kecil seperti Sekarbela jumlah 20-30 orang warga yang menunaikan haji setiap tahun merupakan jumlah yang cukup signifikan.

Salah satu ciri komunitas Islam Sekarbela adalah tradisi pengajian di mesjid, sesuatu yang sulit dipertahankan pada masyarakat relatif terbuka. Dan tradisi pengajian tersebut membawa implikasi pada tidak dimanfaatkannya momentum upacara shalat Jum'at sebagai media untuk menyampaikan pesanpesan keagamaan sebagaimana layaknya mesjid-mesjif lain. Mereka membawakan khutbah dalam Bahasa Arab, sebatas memenuhi ketentuan formal untuk sahnya suatu khutbah Jum'at.

Jum'at ceramah Arab saja, mengingat mereka banyak yang bisnis, cepat mau pulang. Kalau banyak ceramah, banyak habis waktunya. Mereka ada orang dagang, ditunggu sama langganan, jadi cepat mau keluar. Kalau penerangan Islam disini sudah ada lewat pengajian setiap malam. Tiap malam ada di mushallah secara bergilir, tanpa biaya, ba'dal Magrib. Jadi mereka bisa bosan kalau tiap saat disuguhi ceramah terus. Makanya mereka tidak terlalu perlu ceramah Jum'at dan bisa lebih khusyu. Belum lagi pengajian dari rumah ke rumah, yang anggotanya 6 orang atau berapa secara bergilir. 4 .

Meski mereka mencoba untuk merasionalkan dan mengaitkan dengan tuntutan ekonomi, model khutbah semacam itu lebih merupakan suatu keterikatan pada tradisi khutbah yang pada umumnya berlaku di Nusantara, yang kebanyakan ummat Islam sudah meninggalkannya. Hal ini menunjukkan adanya nuansa keberagamaan yang secara lokal tertanam sedemikian dalam melalui genealogi Tuan Guru ke Tuan Guru sepanjang sejarah Islam Sekarbela.

Sama halnya dengan ketertutupan terhadap mubaliiq dari luar Sekarbela. Sangat jarang untuk tidak mengatakan tidak pernah terjadi dalam sejarah pelaksanaan Maulid dan khutbah Jum'at di Sekarbela perceramah atau khatibnya dibawakan oleh orang dari luar Sekarbela. Kenyataan itu dihubungkan dengan standar pengetahuan agama masyarakat Sekarbela yang diakuinya sudah merata dan memiliki standar baku.

Disini orang mengaji bawa kitab, supaya sama-sama memahami, ada standar. Standar umum adalah figih. Makanya mereka sulit menerima kalau bukan dengan cara itu. Menurut Kitab, lebih afdol kita melakukan khutbah pendek daripada 
DIMENSIBUDAYA LOKAL DALAM TRADISI HAUL

DAN MAULIDAN BAGI KOMUNITAS SEKARBELA MATARAM

panjang. Disini masyarakat sudah punya pengetahuan standar mengenai masalah dasar agama. Karena memang mereka malu kepada masyarakat kalau tidak mengaji. Karena itu, mereka tidak cenderung mengambil penceramah dari luar yang tanpa standar. Paling-paling mereka mengangnggap pengetahuannya dengan penceramah kurang lebih sama. Itu di Sekarbela saja yang ketat begitu. Tarekat pun tidak ada. Masyarakat tidak ada waktu untuk kesana. Habis waktunya untuk berusaha. Mereka punya kerja adalah usaha-ngaji, usahangaji..

Adalah suatu yang berlebihan untuk mengatakan bahwa suatu masyarakat kecuali masyarakat santri anggota masyarakatnya memiliki kemampuan rata-rata untuk menghitung faraid-nya (pembagian harta warisan) sendiri. Tapi itulah yang terjadi pada masyarakat Sekarbela. Untuk sekedar menghitung pembagian harta warisan, penghulu biasanya tinggal datang memberikan persetujuan, karena rata-rata mereka sudah dapat melakukannya. ${ }^{6}$.

Masyarakat sudah mampu menghitung pembagian harta warisan sendiri, meski sebagai adat masih perlu menghadirkan pemeritnah. Hukum Islam tentang kewarisan dijalankan masyarakat. Pembagian dilakukan dengan menghadirkan Tuan Guru, bukan KUA. Pembagian tanah, dan harta lainnya dilakukan secara langsung kita disini. Dalam acara pembagian itu diundang penghulu, para kepala kampung, tokoh masyarakat, sampai 10 orang yang penting-penting untuk membagikan harta kepada si anu sesuai anggaran Islam. Waktunya sesudah semua rangkaian upucara kematian selesai, sesudah 100 harinya.

Tradisi pengajian belangsung dalam suatu jaringan laba-laba yang berpusat di pesantren kemudian terjalin keluar ke perkampungan dimana para Tuan Guru dan penghulu memegang peranan penting. Selain melaksanakan tugas-tugas kepenghuluan, kediamannya menjadi sentra pengajian : "Disini malam, pagi ramai pengajian, anak, remaja, dewasa. Pagi mulai shalat subuh sampai jam 10.00 untuk remaja. Orangnya ada yang jauh-jauh. Bergiliran per kampung. Kalau malam anak-anak. ${ }^{8}$

Sistem dan mekanisme solidaritas kelompok dengan semangat keagamaan yang terpelihara melalui sosialisasi lembaga pendidikan keagamaan dan kepastian secara ekonomis menyebabkan kurangnya peluang terjadi alienasi dan patologi sosial bagi remaja Sekarbela. Keresahan yang sering terjadi pada masyarakat akibat prilaku menyimpang dari kalangan kaum muda jarang sekali terjadi. Kalau pun ada yang ingin melakukannya, ia tidak akan melakukan di lingkungan Sekarbela.

Ketegangan yang terjadi akibat dari prilaku ekonomis berorientasi profit misalnya dengan adanya kontroversi mengenai hubungan dengan bank menjadikan orang Sekarbela lebih suka memupuk modal secara mandiri.

Kalau mereka punya uang lebih senang diemaskan. Masyarakat lebih suka berusaha sendiri tanpa ada urusan dan beban dengan bank. Banyak pinjam uang di bank tidak berhasil. Yang seharusnya hasilnya 10,5 juta dilapor di bank 10 juta, jadi hasilnya juga bohong. Awalnya bohong, akhirnya juga bohong. Kalau menurut versi Penghulu, bank dihindari masyarakat karena riba. Syirkah lebih banyak disini. Ada 
DMENSIBUDAYA LOKAL DALAM TRADISI HAUL

DAN MAULIDAN BAGI KOMUNITAS SEKARBELA MATARAM

barang mau dibeli, pinjam uang, kemudian dikembalikan modal/pinjaman bersama keuntungan yang diperoleh dibagi dua. Jadi tidak istilah kontrak, kalau di bank kan kontrak, kerja atau tidak kerja harus sekian persen. Kalau ini tidak. Kalau berhasil atau tidak dibilang. .

Kecenderungan tetap bertahan pada pola konvensional dalam melihat lembaga perbankan lsbih banyak disebabkan oleh selain faktor keterikatan pada norma agama, juga kerena adanya konpensasi terhadap mana saving uang dapat lebih aman, yaitu emas. Dengan mengemaskan uang mereka bisa mengembangkan modal secara mandiri atau secara berkelompok.

\section{Footnote :}

1. Dea Mumbul adalah keturunan raja Sumbawa. Ia dipercayai pernah bertapa di Gunung Rinjani dan kebal terhadap pisau termasuk tidak dapat disunat sehingga akhirnya memeluk Hindu.

2. Cerita diangkat dari dokumen yang ditulis Drs. Zainul Islam pada tanggal 25/12/1995, dengan nara sumber Tuan Guru Haji Muktamad Rais, H. Suhaimi, dan Tuan Guru Haji Marzuki.

3. Fathurahman, Wakil Pimpinan Pondok Pesantren Arraisiyah Sekarbela, Wawancara, 05 Oktober 1996.

4. Farid Wajdi, mahasiswa Universitas Mataram, Wawancara, 05 Oktober 1996.

5. Sama footnote nomor 4

6. H. Syarafuddin, Penghulu Karang Pule, Wawancara, 03 Oktober 1996.

7. Sama footnote nomor 3 .

8. Sama footnote nomor 6 .

9. Sama footnote nomor 3 .

\section{IH. DARI MAULED KE HAUL}

Ada dua upacara keagamaan yang menonjol di Karang Pule, khususnya masyarakat Sekarbela : upacara peringatan Maulid Nabi Muhammad dan Haul Guru Muhammad Rais. Begitu pentingnya kedua upacara tersebut sehingga dapat dikatakan bahwa kehidupan masyarakat Sekarbela secara dominan diwarnai oleh kedua kegiatan ceremonial tersebut.

A.Maulid, antara Tradisi dan Relaksasi.

Bagi Ummat Islam, Nabi Muhammad adalah seorang sosok ideal untuk menjadi teladan, ukuran kebaikan, dan tumpuan kecintaan. Hal itu antara lain, dijelmakan dalam bentuk tradisi Barzanji yang dibacakan dalam upacara-upacara siklus kehidupan. Barzanji, dengan demikian, boleh jadi merupakan sebuah kitab yang paling banyak dibacakan dalam kaitan dengan upacara-upacara, melebihi Alquran sekalipun. Dan apresiasi masyarakat setempat kepada karya yang satu ini relatif merata di kalangan para anggotanya. Sentra-sentra kekuatan tradisi barzanji ini bersimpul di kalangan para haji, yang pada hampir setiap upacara keagamaan mendapat privilese dibanding dengan warga lainnya.

Upacara Maulid merupakan simbol kecintaan kepada Rasulullah Muhammad saw, bertujuan mengenang kembali kissah hidup dan perjuangannya, keteladanannya dan bagaimana beliau membangun masyarakatnya. 'Upacara dilaksanakan empat hari berturut-turut mulai tanggal 12 Rabiul Awal dan seterusnya. Upacara dilaksanakan secara bergiliran pada empat mesjid di Sekarbela dan Karang Pule. (1) Tuan Guru sebagai pemimpin upacara, (2) para haji, (3) tokoh-tokoh agama, (4) tokoh masyarakat.

Bagi masyarakat Sekarbela, Tuan Guru adalah tokoh sentral yang menjadi 
DMENSIBUDAYA LOKAL DALAM TRADISI HAUL

DAN MAULIDAN BAGIKOMUNITAS SEKARBELA MATARAM

rujukan dalam berbagai urusan, tidak terbatas pada urusan keagamaan saja. Dalam urusan kemasyarakatan Tuan Guru adalaah partner dan bahkan merupakan sumber legitimasi bagi pemimpin formal setempat. Tuan Guru inilah sebagai pemeran utama dalam upacara Maulid.

Upacara maulidan juga ditandai dengan dominannya para haji. Boleh dikata acara ini merupakan reuni tahunan dan upacara para haji di Sekarbel. Merekalah peserta inti dan menempati posisi terdepan di dalam mesjid dimana upacara dilaksanakan. Dengan pakaian serba putih, mereka berpindah dari satu mesjid ke mesjid lainnya dalam empat hari upacara dilaksanakan.

Keterlibatan masyarakat umumnya lebih banyak sebagai penggembira. Sedangkan perempuan menyiapkan keperluan upacara, terutama konsumsi. Jenis konsumsi yang disiapkan masyarakat terdiri dari tiga dulang. Dulang pertama dalah jajan, terdiri atas kue-kue tradisional seperti tank, cipuk, naris, tape dan sebagainya. Dulang kedua berisi nasi dan berbagai jenis lauk pauk. Dulang ketiga berisi 5-15 sisir pisang.

Maulid diadakan sehari penuh, makan-makan. Jam 10.00 pakai jajan tradisional (cipuk, tarik, tape, ranis) untuk 4 orang. Jam 13.00 mereka bawa nasi satu dulang dengan isi macam-macam. Menjelang shalat Ashar datang lagi. Sesudah shalat diadakan acara cukuran. Antara jam 10.00-13.00 mereka makan-makan aja. Sesudah makan siang pulang dulu istirahat, nanti menjelang Ashar datang lagi dengan bingkisan khusus pisang 10 15 sisir untuk satu narik (porsi) biasanya untuk 4 orang, untuk penutupan sore. Sesudah makan dibawa pulang sisanya. Semua orang bawa.

Upacara cukuran merupakan rangkai- an akhir dari pesta Maulidan. Tradisi cukuran untuk anak-anak baru lahir di kalangan masyarakat Sekarbela dan Karang Pule merupakan upacara yang dilakukan sebagai ikutan kepada Sunnah Nabi ketika beliau mencukur cucunya Hasan dan Husein. Bagi orang tertentu dapat melakukannya di rumah, tetapi lebih banyak yang menunggu dan membawa ke acara maulid atau ke Haul TGH. Muhammad Rais. Keluarga hanya membawa uang selawat (sedekah) 500 ribu rupiah untuk mesjid.

Alat-alat upacara terdiri dari gunting, beras kuning, bunga-bunga. Kalau dulu sekali uang logam ditarob disana. Nanti beras dan bunga setelah dibawa pulang digiling untuk jadi boresnya (bedaknya) anak supaya cepat besar, ada berkahnya. Kalau sakit-sakit sedikit, badan tidak enak, itu jadi obatnya. Bunga rampai terdiri dari dedaunan, bunga melati, macammacam. Biasanya dijual di pasar. ${ }^{4}$

Jika kebiasaan mencukur anak-anak bayi tujuh hari setelah lahir bersamaan dengan upacara Aqiqah, maka di Sekarbela tentu saja tidak mengikuti pola demikian. Banyak bayi, yang karena hams menunggu waktu upacara Maulid, baru dicukur setelah usia puluhan hari atau bulanan. Caranya, ketika peserta upacara berdiri sambil membaca Asrakah (bahagin tertentu dalam Barzanji, yang ketika dibacakan peserta upacara harus berdiri sebagai simbol penghormatan dan sambutan atas kedatangan Nabi), seorang, biasanya dari kalangan keluarga, menggendong bayi yang akan dicukur dan setiap peserta upacara (dimulai oleh pemimpin upacara) secara bergilir mengguntihg minimal tiga lembar rambut sang bayi. Karena yang dibaca adalah Asrakal badru alaina..., 
DIMENSI BUDAYA LOKAL DALAM TRADISI HAUL

DAN MAULIDAN BAGI KOMUNITAS SEKARBELA MATARAM

maka upacara ini juga disebut Asrakahan. Di waktu lain, dalam upacara siklus hidup atau hajatan, asrakahan merupakan bagian tak terpisahkan dari bacaan barzanji yang untuk membacanya memerlukan waktu 30 - 60 menit.

Meski demikian, Maulid lebih tampak dari aspek seremonial daripada aspek ritual. Hal itu ditandai dengan dominannya unsur konsumsi dan kegiatan relaksasi. Hal yang terakhir ini menjadi acara yang melebihi keramaian lain setiap tahun, khusus bagi anak-anak dan pemuda, meski dengan permainan yang amat sederhana, murah tapi meriah, seperti tarik tambang, lomba karung, ketangkasan panjat pinang (yang dilicinkan dengan gemuk dan di bagian puncaknya digantung berbagai hadiah seperti baju, celana, sebagai target). Ada juga permainan buah jeruk besar digantung. Permukaannyadiolesi arang camput mianya dan di'empeli sejumlah uang logam. Uang yang tertempel kemudian diperubutkan dengan cara menggigit. Dengan demikian, selain sebagai acara keagamaan, maulid juga telah menjadi acara seremonial yang melibatkan semua kalangan dan lapisan masyarakat. Pada malam harinya dilakukan kegiatan seni dan ketermpilan, seperti cerdas cermat.

Maulidan selain dilaksanakan di masjid, juga dirumah-rumah. Warga secara sendiri-sendiri melaksanakan maulid di rumah masing-masing. Kesempatan itu, biasanya dipergunakan untuk mengundang keluarga lain dan rekanan bisnisnya. Berbeda dengan di mesjid, acara yang dilaksanakan di rumah lebih simpel dan yang lebih menonjol adalah icdszmakan-makan. Tampaknya mereka, menyiapkan konsumsi sekaligus. Selain dibawa ke masjid, sebagiannya lagi disuguhkan di rumah. Dengan demikian, dalam empat hari di bulan Rabiul Awal, Sekarbela larut dalam suasana suci dan semarak. Kesibukan sehari-hari untuk mencari nafkah berubah menjadi suasana rileks.

Secara ekonomis, Maulid merupakan salah satu tradisi terhadap apa warga masyarakat paling banyak memberikan kontribusi yang cukup besar. Rata-rata rumah tangga di Sekarbela mengeluarkan biaya 50.000.- rupiah. Bahkan bagi tokoh adat bisa sampai 500.000,- rupiah. Sehingga ada kesan, masyarakat Sekarbela mencari nafkah dalam setahun untuk biaya upacara Maulid dan Haul.

Dulu-dulu, dapat dikatakan berani bernntung untuk merayakan Maulid. Misalnya sembelih sapi 2-3 ekor untuk satu kampung. Jadi masyarakat kampung itu ambil barang sekilo dua kilo, nanti tiga bulan kemudian, saat panen dibayar. Tapi sekarang tidak kelihatan karena meningkatnya ekonomi masyarakat, makin bagus. Itu yang saya temui dulu-dulu. Saya sebagai yang sudah mendapatkan wawasan pendidikan tentang Sosiologi, budaya, saya pikir kalau mau ubah sulit juga. Karena generasi tua melestarikan, karena walaupun kita anak-anak itu ingin merombak, kan bumerang. Jadi kami ambil positifnya, ukhuwah islamiyahnya itu. Kalau kami lihat dari suguhan makanan melebihi, katakanlah kalau kita lihat makanan yang disuguhkan iiu, makanan sebulan habis sekali, begitu. Pesta betul. Dan itu di semua rumah, seluruh masyarakat. Semiskin-miskinnya orang bisa habis 50 ribu, minimal. Kalau seperti saya, ketua adat, meski masih anak-anak Ibu minta untuk kue-kue 200 ribu, besok untuk beli daging hari H-nya sampai 300 ribu habis. Belum lagi untuk Iain-Iain.' 
DIMENSIBUDAYA LOKAL DALAM TRADISI HAUL

DAN MAULID AN BAGI KOMUNITAS SEKARBELA MATARAM

Untuk mengeluarkan biaya sebesar itu, bagi orang Sekarbela bukanlah sesuatu yang berat. Di samping sudah merupakan suatu tradisi, mereka juga memiliki standar ekonomi yang relatif cukup bagus untuk ukuran masyarakat setempat, berkat dari usaha dan kerajinan emas. Bahkanbagi sebagian besar dari mereka itu belum seberapa.

Meski demikian, bukan tidak timbul kritik dari kalangan mereka sendiri, khususnya dari kalangan generasi muda yang karena pendidikannya yang sudah relatif maju melihat adanya kesan pemborosan yang terkait dengan upacara Maulid.

Pelaksanaan maulid disini kurang efektif. Lebih banyak mengeluarkan dana, mending dana itu diirit dan disalurkan ke pengusaha kecil, yang bermanfaat. Tetapi karena ini tradisi agama, yah sulit. Saya kurang simpatik dengan caranya. Mereka datang hanya zikir (kalau tidak salah) tidak ada hikmah. Meski acaranya sampai sore, paginya jajan, siangnya nasi, sorenya buah. Tiga kali mereka hadir. Pagi sampai sore hanya makan. Yang besar biayanya maulid. Bisa lipat dua kali biayanya. Dulu barangkali mereka memiliki persiapan cukup lama untuk membiayai kedua acara tersebut. (haul dan maulid, pen.). Tetapi sekarang mereka tidak merasa berat dengan biaya sebesar itu. Pertama, ekonomi, kedua tikda jadi beban, semacam rutinitas dan keikhlasannya. Maulid itu sebenarnya harus dikembangkan kepada hal-hal yang bisa mengungkap bagaimana cara-cara Nabi mensikapi atau bagaimana kita mensikapi cara Nabi terhadap masalah sosial. Ini pemborbsan. Hanya zikir, tidak ada uraian, tidak saling meningatkan. ${ }^{8}$
Karena kuatnya sistem komunitas Sekarbela, kesadaran baru di kalangan generasi muda, tidak sampai menimbulkan konflik. Sebaliknya, yang terjadi adalah akomodasi kepentingan generasi muda tersebut ke dalam sistem upacara. Misalnya dengan dimasukkannya unsur permainan, perlombaan seperti cerdas cermat, lari karung, dan jenis-jenis keramaian yang disebutkan sebelumnya. Sebagai suatu tradisi yang sudah berlangsung demikian lama dalam sejarah komunitas Sekarbela, upacara Maulid sudah berkembang menjadi nilai dominan dalam proses sosialisasi dan menjadi milik semua warga. Suatu nilai disebut dominan, apabila

Williams mengajukan empat kriteria untuk mengukur kedominanan suatu nilai pada diri seseorang atau kelompok, yaitu (1) extensiveness of the value in total activitity, (2) duration of the value, (3) intesity with which tha balue is sought or maintained, (4) prestige of value carries (Rush Karim, 1982 : 1991). Yang dimaksud Williams adalah suatu nilai dianggap dominan atau tidak tergantung pada luas tidaknya pengaruh nilai tersebut dalam seluruh aktivitas masyarakat ; gigih tidaknya nilai tersebut diperjuangkan atau dipertahankan oleh masyarakat; dan tinggi rendahnya prestise atau penghargaan yang diberikan masyarakat terhadap penganut nilai tersebut.

Kendati merupakan kenyataan budaya yang demikian berakar di masyarakat, tidak cukup jelas faktor historis dari upacara tersebut tersosialisasikan dari generasi ke generasi. Selain secara umum dikleim sebagai suatu cara menghormati dan mencintai Rasulullah tidak tersosialisasikan dengan jelas mengapa Maulid itu berkembang secara khas keluar dari trend umum upacara Maulid di masyarakat Lombok. Generasi sekarang menerimanya sebagai sebuah warisan para pendahulu. 
DMENSIBUDAYA LOKAL DALAM TRADISI HAUL

DAN MAULIDAN BAGI KOMUNITAS SEKARBELA MATARAM

Kami tidak tahu asal muasalnya, tapi sudah berurat berakar di masyarakat. Saya sendiri sudah 38 tahun Iahir dan tahu persis suasananya dari dulu sudah begini yang saya dapati. Jadi pada saat kami kecil tradisi kami itu seakan-akan mengumpulkan dana untuk satu tahun untuk perayaan besar hari Maulid itu. Betul-betuI pada saat itu terjadi silaturahmi yang tinggi dalam arti kerabat, sahabat, keluarga yang jauh-jauh itu diundang dihidangkan makanan lauk pauk, yang hanya dibuat sekali setahun, yang bumbu-bumbunya dibuat sedemikian rupa, makanan ciri khas. Pada saat itu dari antara mesjid ke mesjid antara kampung ke kampung saling mengundang. Jadi kami sebagai tokoh adat karena jabatan formal seperti lurah yah harus begitu. Otomatis. Biar kita masih anak-anak, tetapi karena jabatan maka kita sebagai tokoh adat, atau ditokohkan, dan itu punya konsekuensi sosial. Generasi muda juga ikut, tidak ada gap. ${ }^{\prime}$

Masyarakat Sekarbela merupakan suatu komunitas dengan kesadaran dan kesinambungan sejarah yang unik. Mereka memahami keberadaannya sebagai pembela agama Islam, sebagaimana arti yang terkandung dari Sekarbela. Kesadaran sejarah itu dimungkinkan oleh munculnya matarantai ulama yang tidak pernah putus dari periode ke periode, mulai dari Gaus Abdul Razak, Tuan Guru Haji Muhammad Rais, dan sekarang TGH Muktamad Rais bersaudara dan muridmurid TGH Muhammad Rais lainnya. Perjalanan sejarahnya diwarnai oleh peristiwa-peristiwa yang memperhadapkan komunitas Sekarbela kepada pilihan membela diri baik terhadap dominasi kekuasaan Anak Agung ;maupun terhadap kekuatan lain, yang meronrong eksistensi Islam dan komunitas Sekarbela, yang datang sesudahnya. Maulid dalam konteks ini merupakan faktor pemupuk solidaritas kelompok sekaligus salah satu unsur untuk memperkuat mekanisme ketahanan kelompok, mengikuti sejarah timbulnya Maulid di zaman Salahuddin Al-Ayyubi, seperti dibaca dalam referensi Islam klassik.

Itulah sebabnya upacara Maulid dirayakan secara khas melebihi upacaraupacara manapaun di Sekarbela, tidak peduli berapa banyak biaya dikeluarkan untuk itu.

Kalau Maulid semua rumah dihias lampu-lampu, yang kedap-kedip segala macam. Lebih dari 50 tahun merdeka. Kalau Agustusan malah tidak ada disini, paling-paling ktia buat gapura saja. Yang rayakan hanya di Mataram. Kalau Muharram, tidak pernah dirayakan disini. Kecuali shalat saja pada malam Muharram. Isra diadakan juga tapi tidak seramai Maulid : Sepi ${ }^{10}$

B. TGH Muhammad Rais dan Genealogi Kebaramaan Sekarbela

Almarhum Tuan Guru Haji (TGH) Muhammad Rais dilahirkan 141 tahun yang lalu tepatnya pada tahun $1855 \mathrm{M}$ dnegan usia 112 tahun meninggal pada hari Senin 8 Januari 1967, bertepatan dengan 8 Syawal $1387 \mathrm{H}$. Rais adalah ulama tertua dan dituakan di Sekarbela dan sekietarnya. Sebelum menetap di Sekarbela, Rais tinggal di wilayah Pesinggahan. Selama hidupnya TGH Muh. Rais merupakan tokoh agama tertua dan dituakan di Sekarbela. Beliau sempat menetap di Mekah selama 7 tahun sejak usia 42 tahun. Selama di Mekah secara khusus beliau mendalami Ilmu Nahwu dan Sharaf pada Syekh Suaib Maghraby di 
DIMENSIBUDAYA LOKAL DALAM TRADISI HAUL DAN MAULIDAN BAGI KOMUNITAS SEKARBELA MATARAM

samping berguru pada TGH Umar Kelayu yang tinggal dr Mekah. Beliau juga belajar dari Tuan Guru Haji Tayyib Gubuk Memben dan TGH Badar putra TGH Umar.

Sekembalinya dari Mekah beliau mengajarkan ilmu yang telah diperolehnya. Sebagai murid pertamanya adalah TGH Abdurrahman (Balok Tuan Amang) Sekarbela. Walaupun selama 7 tahun bersama TGH Tayyib di Mekah namun, TGH Tayyib terlebih dahulu menjadi alim, meski ia tetap mengakui adanya kelebihan yang dimiliki TGH Muhammad Rais. Bahkan TGH Tayyib sendiri sempat mengaji pada TGH Muhammad Rais untuk mendalami hal-hal tertentu dari ajaran Islam. Potensi yang dimiliki TGH Muhammad Rais, kemudian oleh TGH Tayyib disampaikan kepada orang tuanya, Amaq Jumaiyah, tokoh dan pejuang Sekarbela. Mendengar informasi tersebut Amaq langsung bangkit menuju ke mesjid memukul beduk untuk mengumumkan kepada masyarakat Sekarbela penobatan Muhammad Rais sebagai Tuan Guru, terhadap siapa mereka harus belajar Islam dan menerima nasehatnya.

Dari Pesinggahan TGH Rais pindah ke Sekarbela dan tempat yang baru ini beliau mendirikan sebuah Bale Tajuk sebagai sarana tempat mengajar. Bali Tajuk ini merupakan bangunan sederhana beratapkan alang-alang tanpa tembok dan bedek serta barlantaikan tanah. Di tempat inilah beliau mencetak para tuan guru tidak saja dari lingkungan Sekarbela tetapi termasuk dari luar seperti Karek, Praya, Pagutan, Mamben, dan lainnya.

Beberapa nama murid beliau tercatat antara lain TGH Abdurrahman Sekarbela, TGH Tayyib Gubuk Memben, TGH Mustain Gubuk Mamben, TGH. Ibrahim Praya, TGH. Umar Kapek, TGH Muin Kapek, TGH Muksin Seganteng, TGH. Tahir Persinggahan, Saleh Mamben,
TGH Jaelani dan TGH Mustajab Pagutan, TGH. Muh. Toha Karang Pule, TGH Mustafa Bakri Banjar, TGH Syafii Gubuk Mamben, TGH Syafii Sekarbela, TGH Jalaluddin, TGH Fadil, TGH Jabar, TGH Syafri, Guru Sakti, serta tidak ketinggalan putra dan keluarga beliau TGH Muktamad Rais, Drs. H. Maqsud Rais, TGH Marzuki dan generasi penerus lainnya.

Di samping sebagai tokoh agama beliau juga pemimpin perlawanan terhadap PKI melalui Banser Ansor. Petuah beliau dalam bentuk sindiran yang dituangkan dalam Bahasa Sasak antara lain :

- Kuao pondong jagung, semarang tao ie jagung.

- Manok panggang kurang nan regi, tadahne tandang ndek ne tao ngeji.

Ketokohan TGH Muhammad Rais di kalangan masyarakat Sekarbela dan sekitarnya menyebabkan banyaknya berkembang cerita menarik di sekitar kehidupannya.

TGH Zainuddin di Pancor (ulama paling sepuh di kawasan Lombok saat ini), diceritakan sebagai memiliki hubungan baik dengan TGH Muhammad Rais dan sering bertukar pikiran sampai ke tingkat minta fatwa. Rais memang lebih senior dari Zainuddin. Rais dikenal ahli dalam bidang Nahwu, melebihi ulama manapun di Lombok pada zamannya. Dua orang putranya yaitu TGH. Muktamad Rais dan TGH Drs. H. Maksud Rais berusaha melanjutkan genealogi keilmuan tersebut melalui Pondok Pesantren Arraisiyah. Keahliannya itu membawa kapasitas penguasaan kitab-kitab klassik yang dikenal dalam tradisi pesantren.

Sebagai seorang ulama, ia tidak saja amat dicintai oleh murid-muridnya, tetapi juga sudah menjadi simbol kewibawaan Sekarbela. Realitas kecintaan dankebesaran selain tampak pada respek masyarakat melalui kuburnya yang sampai sekarang ramai dikunjungi peziarah untuk 
DIMENSI BUDAYA LOKAL DALAM TRADISI HAUL

DAN MAULIDAN BAGI KOMUNITAS SEKARBELA MATARAM

zikir, baca Alquran, melepas nazar, bacakan Yasin; juga adanya tradisi Haul memperingati hari kematiannya dan berdirinya sebuah yayasan pendidikan untuk namanya.

Kuburnya ramai dikunjungi tiap malam Jum'at dan pagi Jum'at oleh orang sini, banyak juga orang luar untuk ziarah, baca yasinan dan sebagainya.

\section{Haul dan Missi Pesantren}

Upacara terbesar sesudah Maulid di kalangan masyarakat Sekarbela adalah Haul yang diadakan untuk memperingati kematian dan melestarikan pelajaran TGH Muhammad Rais. ${ }^{12}$ Dilaksanakan setiap tanggal 8 Syawal, haul TGH Muhammad Rais sudah berlangsung selama 28 tahun sejak kematiannya. Hari itu bertepatan dengan Lebaran tupat ${ }^{13}$ yakni lebaran sesudah melaksanakan Puasa Sunat 6 hari menyusul lebaran Iedul Fitri. Lebaran kedua ini biasanya lebih ramai dari lebaran Iedul Fitri.

Pelaksanaan Haul dilakukan oleh masyarakat Sekarbela, dibawa kendali Kepala Lingkungan Pandemas Timur dan pihak keluarga. Masyarakat dengan sukarela membawa makanan (dulang, Sasak) yang sudah siap dihidangkan, sehingga pihak keluarga almarhum tidak perlu mengeluarkan biaya untuk menjamu para undangan. Setiap rumah tangga mengeluarkan sedikitnya 20-30 ribu rupiah untuk membiayai makanan (terdiri dari nasi dan berbagai jenis lauk pauk) yang dibawa ke upacara haul. Dan, sebagai mana halnya dengan prilaku masyarakat terhadap Maulid, hal ini berlangsung spontan. Partisipasi Haul dapat mencapai ribuan orang datang dari berbagai penjuru Lombok, undangan, dari pihak Pemerintahan dan masyarakat setempat.

Har.l Rais, secara kebetulan memang tuan guru meninggal pada saat lebaran tupat. Sekaligus acara syukuran dan masyarakat yang mengeluarkan makanan satu dulang. Tuan Guru mengundang pimpinan formal, dan orang lain di luar. Tuan guru tidak siapkan apa-

Upacara haul diadakan di kompleks Pesantren Arraisiyah di sebuah kampung bernama Uda-Uda. Berlangsung selama 3-4 jam Gam 08.00 - 11.00) acara Haul cukup sederhana. Acara formal diawali ceramah mengenai sejarah singkat kehidupan TGH Muhammad Rais, dibawakan oleh pihak keluarga. Sesudah itu sambutan pemerintah dan akhirnya makan. Pada malam hari pelaksanaan upacara masyarakat membacakan yasinan di makam almarhum, terletak di dalam kompleks Pesantren. Setelah upacara formal selesai kemudian masyarakat melanjutkan dengan upacara cukuran bagi anak-anak bayi, sama yang dilakukan pada waktu upacara peringatan Maulid Nabi Muhammad saw. Hal itu dijadikan motivasi dan untuk mengambil berkah dari peristiwa tersebut.

Keterlibatan masyarakat dalam haul sukarela. Tanpa diminta mereka ikut. Masyarakat juga membawa anaknya untuk dicukur, dan dikhitan. Untuk itu, mereka minimal menghabiskan 20 - 25 ribu untuk menyiapkan makanan dan itu tidak berat bagi masyarakat sini. ${ }^{16}$

Sama dengan sikap masyarakat terhadap Maulid, haul berlangsung sebagai sebuah tradisi, tidak ada yang menggiigat meski ada yang menuntut agar maknanya bisa ditangkap lebih dari sekedar upacara seremonial. Sebab dengan demikian, yang tampak dalam kasus upacara haul adalah sikap religiusness (sikap menyerah kepada agama), lebih dari sikap religious mindedness (sikap mengembangkan cara beragama) (Geertz, 1982 : 24). 
DIMENSIBUDAYA LOKAL DALAM TRADISI HAUL

DAN MAULIDAN BAGI KOMUNITAS SEKARBELA MATARAM

Mengenai haul, lebih karena ilmunya bukan karena personnya atau kultus. Jadi penghormatan sebagai orang berilmulah yang membuat masyarakast memperingati haul. Keluarganya, kalau tidak punya ilmu dan perilakunya tidak sesuai, tetap saja tidak dihargai. Tetapi ada sebagian sikap masyarakat yang berkembang negatif yaitu orientasi masa lampau yang cukup besar, terutama bagi yang tua-tua tetapi juga yang muda. Tidak bagaimana berfikir agar anaknya lebih dari itu. Jadikan haul sebagai sumber motivasi. ${ }^{17}$

Obsesi kalangan muda itu sebagiannya telah terwujud lewat pendirian Yayasan Pondok Pesantren Arraisiyah pada tanggal 27 Oktober 1986/23 Syafar 1407 H. dengan mengambil nama TGH Muhammad Rais sebagai nama lembaga pesantren tersebut. Pesantren itulah bentuk konkrit dari haul. Dan ternyata, seperti juga haul, masyarakat Sekarbela mendukungnya tanpa reserve. Dukungan masyarakat terhadap pesantren inilah yang membuat pelaksanaan haul cenderung semakin berkembang.

Kecenderungan haul semakin ramai, terutama karena mereka juga mau melihat pondok pesantren. Pada kesempatan itu, sesudah acara haul, kita ungkapkan masalah pesantren. Pengusaha dipanggil khusus untuk membicarakan pembangunan pondok pesan tren. ${ }^{18}$

\section{PENUTUP}

\section{Kesimpulan}

Maulid dan Haul adalah dua upacara keagamaan yang memiliki dimensi tradisional dan lokal cukup kental di Sekarbela. Kedua upacara tersebut sudah berlangsung lama hingga menjadi tradisi dalam sejarah komunitas Sasak yang bermukim di pnggiran kota Mataram itu. Sebagai tradisi pengaruh budaya lokal terhadap pelaksanaan upacara terjalin ke dalam struktur setiap dimensi struktur upacara, membedakannya dari upacara serupa di tempat lain. Dalam kedua upacara itu, seubstansinya adalah ekspressi rasa cinta, mengenang dan melestarikan perjuangan tokoh yang telah tiada : yang satu adalah tokoh universal, Rasulullah Muhammad saw, dan yang kedua adalah tokoh lokal, TGH. Muhammad Rais. jika untuk Nabi simbol peringatan adalah Kelahiran, maka untuk tokoh lokal simbolnya adalah saat kematian. Tetapi substansinya relatif sama : mengacu kepada pengungkapan kembali perikehidupan sang tokoh.

Peran Tuan Guru amat dominan untuk kedua upacara. Hal ini merupakan ekspansi dari posisi sentral para Tuan Guru sebagai pemberi legitimasi terhadap programprogram pembangunan secara umum, dan tingginya prestise yang diberikan masyarakat kepadanya dalam hirarki dan struktur keagamaan. Meski demikian, arti ketokohan Tuan Guru hanya bermakna apabila didukung oleh masyarakat. Dan ternyata dukungan masyarakat terhadap kedua upacara tradisional tersebut bersifat total. Mereka adalah sumber dari sumberdaya pendukung yang dibutuhkan : sumberdaya kepercayaan, sumberdaya ekonomi, dan ketenagaan. Semuanya diarahkan untuk menyukseskan upacara. Tampak dengan jelas, seakan-akan mereka hidup untuk kedua upacara itu.

Yang tampak di permukaan adalah kemeriahan dengan dominannya simbol makanan. Semua orang menyumbang makanan dan kemudian makan bersama. Dari sini kemudian upacara sakral berkembang menjadi subuah pesta. Banyak keramaian ditampilkan dalam pesta, khususnya olahraga yang murah tapi meriah. Masyarakat ingin rileks dengan upacara itu. Sebagai 
DIMENSIBUDAYA LOKAL DALAM TRADISI HAUL

DAN MAULIDAN BAGI KOMUNITAS SEKARBELA MATARAM

upacara komunal dan massif tidak ada yang secara terang-terangan menggugat, meski dalam pembicaraan individual timbul keinginan upacara dilihat dari segi fungsional pragmatis, terutama untuk pemberdayaan ummat.

Dalam banyak hal kemampuan mempertahankan dan mengembangkan tradisi upacara tersebut karena didukung oleh faktor kemandirian ekonomi. Dengan basis ekonomi rumah tangga yang bergerak di bidang kerajinan emas, warga Sekarbela merupakan sedikit contoh dari masyarakat yang memiliki tradisi upacara cukup tinggi dan makan biaya.

\section{Implikasi Penelitian}

Upacara Maulid dan Haul merupakan asset masyarakat setempat untuk penguatan solidaritas kelompok dan selanjutnya keutuhan bangsa. Karena itu, perlu didukung oleh semua pihak, terutama untuk mengembangkan nuansa lokal pada saat arus pengaruh budaya asing mendera demikian kuat seperti sekarang dan di masa depan pada masyarakat bangsa Indonesia.

Potensi budaya lokal dengan dukungan pusat kerajinan emas yang mengembangkan sikap kemandirian dapat dijadikan dasar bagi pengembangan wisata religius sebagai alternatif bagi obyek-obyek wisata yang belakangan ini berkembang cukup terbuka di NTB, misalnya Senggigi, yang terletak tidak cukup jauh dari Sekarbela.

\section{KEPUTSTAKAAN}

Departemen Pendidikan dan Kebudayaan RI, Monografi Daerah Nusa Tenggara Barat, 1977.

Geertz, C, Islam Yang Soya Amati, YIIS, 1982.

Islam, Zainul, Riwayat Asal Usui Kerajaan Lombok, 1995.

Koentjaraningrat, Pengantar Ilmu Antropologi, Aksara Baru, 1985.

, Beberapa Pokok Antropologi Sosial, PT. Dian Rakyat, 1985.

Pesantren Arraisiyah, Sejarah Berdirinya Pondok Pesantren Arraisiyah, 1994, tidak diterbitkan. 